\title{
The Competitive Advantages of Vietnam Footwear Industry: An Analysis
}

\author{
Xuan Thi Thanh Phan ${ }^{1}$, Cuong Hung Pham $^{2}$ \& Long Pham ${ }^{3}$ \\ ${ }^{1}$ Vietnam Leather Footwear and Handbag Association, Vietnam \\ ${ }^{2}$ Foreign Trade University, Ho Chi Minh City Campus, Vietnam \\ ${ }^{3}$ National Economics University, Vietnam \\ Correspondence: Cuong Hung Pham, Foreign Trade University, Ho Chi Minh City Campus, \#15D5, Ward 25, Binh \\ Thanh District, Ho Chi Minh City, Vietnam.
}

Received: April 14, 2016

Accepted: May 4, 2016

Online Published: May 13, 2016

doi:10.5430/ijfr.v7n3p65

URL: http://dx.doi.org/10.5430/ijfr.v7n3p65

\begin{abstract}
This research The Competitive Advantages Of Vietnam Footwear Industry: An Analysis conducted during the period from January2014 to January2016. The research result showed that there were 500 enterprisesrelated footwear but 458 processed and 42 missed. Besides, all of enterprisesinterviewed and answered nearly 23 questions. The researcher had analyzed KMO test, the result of KMO analysis used for multiple regression analysis. The enterprise responses measured through an adapted questionnaire on a 5-point Likert scale. Hard copy and interviewenterpriseby questionnaire distributed among enterprisesof the provinces of Vietnam. The regression analysis results showed that there were four factors, which included of factors following: Strengths (S), Weakness (W), Opportunity (O) and Threat $(\mathrm{T})$ actually affected the competitive advantages of Vietnam footwear industrywith $5 \%$ significance level.
\end{abstract}

Keywords: competitive advantage, footwear industry, Vietnam

\section{Introduction}

Vietnam footwear industry has been growing significantly from the past few years with rising exports in the international market. In Vietnam, the leather and footwear sector has posted impressive growth in recent years to become the third biggest export earner behind garment and textile and crude oil, the Ministry of Industry and Trade-run institute reported. Vietnam had ranked 4th globally in footwear exports, selling its products to 50 countries and territories, with the EU, US, and Japan being the main buyers. The main export items are sports, canvas, and footwear industry and sandals. The industry now exports up to $90 \%$ of its output. However, similar to footwear and garments, the Vietnam's leather and footwear industry had a difficult year in 2009 as it failed to achieve its export target. According to Ms Nguyen Thi Tong, Secretary General of the Vietnam Leather and Footwear Association (LEFASO), the industry is struggling to cope with shortages in labor, materials and, especially, export markets, reported Vietnam Investment Review. She said that even though Vietnam was one of the largest footwear exporters in the world but the industry still lacked the ability to design its own models and had small-scale production and limited service infrastructure. Vietnam's footwear industry accounts for $8 \%-10 \%$ of the total annual export turnover; being the 3rd important product after footwear, mobile and components. Exports of footwear products were worth US $\$ 8.764$ billion in 2012, US\$8.4 billion in 2013, and US\$10.3 billion in 2014. In 2015, it is highly likely that the sector will reach its target, reaching approximately US\$ $13.5-14$ billion total export turnover and $65 \%-70 \%$ localization rate. This is because a great number of footwear exporting enterprises have signed their contracts until the end of Q III, or even Q IV-2015 while exporting prices to most of the markets such as the United States, Japan, Australia, and South America are stable, or even rise as a result of increased minimum wage in Vietnam.

\section{Literature Review}

Competitive advantage is what a business has over its competitors. This can be gained by offering clients better and greater value. Advertising products or services with lower prices or higher quality interests consumers. Target markets recognize these unique products or services. This is the reason behind brand loyalty, why customers prefer that particular product or service. Competitive advantage is what a business has over its competitors. This can be gained by offering clients better and greater value. Advertising products or services with lower prices or higher 
quality interests consumers. Target markets recognize these unique products or services. This is the reason behind brand loyalty, why customers prefer that particular product or service. Value proposition is important when understanding competitive advantage. If the value proposition is affective clarification needed it can produce a competitive advantage in either the product or service. The value proposition can increase customer expectations and choices.

Competitive advantage seeks to address some of the criticisms of comparative advantage. Porter proposed the theory in 1985. Porter emphasizes productivity growth as the focus of national strategies. Competitive advantage rests on the notion that cheap labor is ubiquitous and natural resources are not necessary for a good economy. The other theory, comparative advantage, can lead countries to specialize in exporting primary goods and raw materials that trap countries in low-wage economies due to terms of trade. Competitive advantage attempts to correct for this issue by stressing maximizing scale economies in goods and services that garner premium prices (Stutz and Warf 2009). The term competitive advantage refers to the ability gained through attributes and resources to perform at a higher level than others in the same industry or market (Christensen and Fahey 1984, Kay 1994, Porter 1980 cited by Chacarbaghi and Lynch 1999, p. 45). The study of such advantage has attracted profound research interest due to contemporary issues regarding superior performance levels of firms in the present competitive market conditions. "A firm is said to have a competitive advantage when it is implementing a value creating strategy not simultaneously being implemented by any current or potential player" (Barney 1991 cited by Clulow et al.2003, p. 221).

Successfully implemented strategies will lift a firm to superior performance by facilitating the firm with competitive advantage to outperform current or potential players (Passemard and Calantone 2000, p. 18). To gain competitive advantage, a business strategy of a firm manipulates the various resources over which it has direct control and these resources have the ability to generate competitive advantage (Reed and Fillippi 1990 cited by Rijamampianina 2003, p. 362). Superior performance outcomes and superiority in production resources reflects competitive advantage (Day and Wesley 1988 cited by Lau 2002, p. 125).

Above writings signify competitive advantage as the ability to stay ahead of present or potential competition. Also, it provides the understanding that resources held by a firm and the business strategy will have a profound impact on generating competitive advantage. Powell (2001, p. 132) views business strategy as the tool that manipulates the resources and create competitive advantage, hence, viable business strategy may not be adequate unless it possess control over unique resources that has the ability to create such a unique advantage.

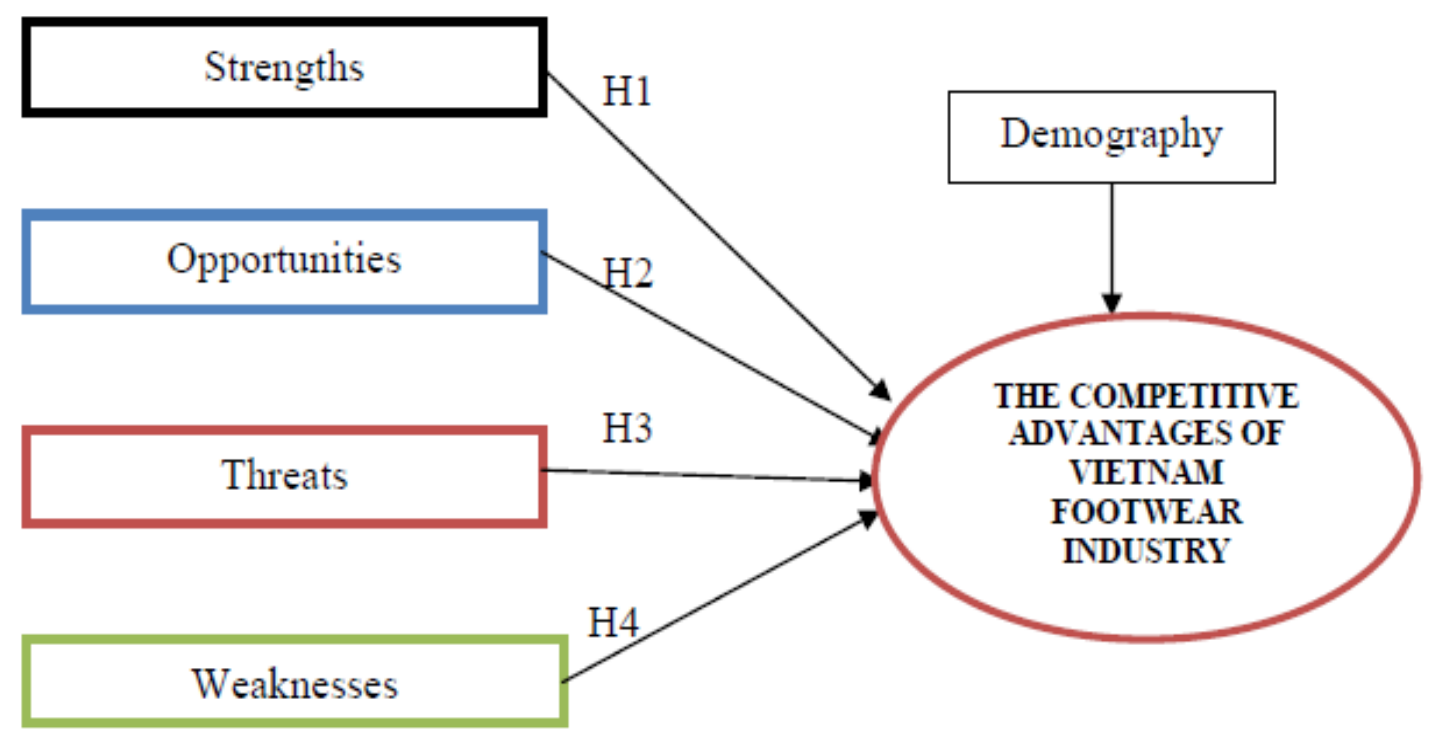

Figure 1. Research model for the factors affecting the competitive advantages of Vietnam footwear industry

Figure 1 showed that the various factors such as Strengths, Opportunities, Threats and Weaknesses affecting the competitive advantages of Vietnam footwear industry.

Based on the aforementioned research questions the following hypotheses used to investigate each question: 


\section{Hypothesis}

H1: There is a positive relationship between Strengthsand the competitive advantages of Vietnam footwear industry.

H2: There is a positive relationship between Opportunitiesand the competitive advantages of Vietnam footwear industry.

H3: There is a positive relationship between Threatsand the competitive advantages of Vietnam footwear industry.

H4: There is a positive relationship between Weaknessesand the competitive advantages of Vietnam footwear industry.

\section{Research Methods}

\subsection{Methods and Techniques of the Study}

This study is a theoretical study of the influence internal and external analysis on the competitive advantages of Vietnam footwear industry.In this study, there are consists of two phases: First: it is a preliminarystudy; I survey 30 economic experts to check the research model. Then the second phase is a formal and more comprehensive study. This study is done by qualitative methods. The research is done by formal quantitative methods. Unit of analysis is a consumer. Study subjects are footwear enterprises of provinces.

As part of the research strategy, qualitative and quantitative data were collected both from primary and secondary data sources, as an input for the finding of this research. Primary data were obtained through semi structured interview from footwear enterprises.

\subsection{Population and Sample of the Study}

The population of this study was all enterprises of provinces of Vietnam. In Vietnam, there are more than 500.000 enterprises of provinces of Vietnambut more than 1.500 footwear enterprisesthat the values of the random variable of interest could possibly be determined. This notion corresponds directly to the frame in sample survey literature. The difference between the attributes of interest in the study population and the corresponding attributes in the target population called the study error. This is a simple quantitative assessment for numerical attributes but can be challenging to define for graphical ones. The study population and the study units were very different from the target in this instance. The statistical method ensures consideration of the relevance of the study population to the target population by forcing investigators to deal directly with the study error. Criteria beyond the study error such as cost, convenience, and ethics is important in determining the study population. After preliminary investigations, formal research done by using quantitative methods questionnaire survey of 500footwear enterprises of provinces of Vietnam.

\subsection{Research Instrument}

My questions used in the survey will consist of two main parts to seek 500footwear enterprises of provinces of Vietnam concerning the competitive advantages of Vietnam footwear industry. In this study, I intend to find out what enterprises of provinces of Vietnam expect in the competitive advantages of Vietnam footwear industry. I arrange the questions about the terms of expectation firstly. I think that for some people, when they reflect on their experiences in the competitive advantages of Vietnam footwear industry, they may have more feelings when answering. This is good for measuring time experience in using footwear enterprises, because their emotions are activated, they will better reflect the image of their moments in the competitive advantages of Vietnam footwear industry and the best assessment of their experience. However, these feelings are not important in measuring their expectations. Qualitative method used to explore any new factors affecting the competitive advantages of Vietnam footwear industry. The questions for interview consisted of several open-ended questions mainly asking whom and what influenced the competitive advantages of Vietnam footwear industry. The findings from qualitative research would add to the input of questionnaire design in the quantitative research. Then the first draft of the questionnaire designed and went through a pilot test to check the comprehensibility and wording of the questions. Next, the quantitative research conducted with the final version of the questionnaire. The quantitative method used to collect data to answer research questions.

\subsection{Data Gathering Procedure}

The instrument for data collection was a self-administrated questionnaire. The questionnaire designed to ascertain the demographic profile of the persons. The factors influence the competitive advantages of Vietnam footwear industry. 
To get the information, the researcher visited to interview 500footwear consumers to answer the survey questionnaire. Besides, the researcher also asked consumers to introduce other enterprises who could take the survey in a voluntary manner. The actual number of respondents in this research is 500 the footwear enterprises of provinces of Vietnam. The data collected and analyzed using the statistical indicators with data processing software SPSS 20.0. The targets include descriptive statistics, reliability analysis, correlation analysis, factor analysis explore, analyze multiple linear regression and ANOVA analysis.

\subsection{Data Processing and Statistical Treatment}

The data collected by the researcher and be analyzed by SPSS. Before having analyzed, the data screened to delete outliners to secure reliability. Formal research used quantitative methods through surveying about 500 the footwear enterprises of provinces of Vietnam. In Vietnam, there are more than 500.000 enterprises but 1.500 footwear enterprises. First, authors had surveyed 100 enterprises related footwear of Dong Nai province. Dong Nai province has more than 300 enterprises. Second, I had surveyed 300 enterprises related footwear of Ho Chi Minh City. Ho Chi Minh City has more than 600 enterprises. Finally, I had surveyed 100 enterprises related footwear of Binh Duong province. Binh Duong province has more than 300 enterprises.

\subsection{Statistical Treatment}

After collecting data, I use Statistical Package for Social Scientists (SPSS) software version 20.0.SPSS for analyzing data and extracting output. There are four tests applied, the order and purpose is described as following:

The observed data was calculated by minimizing the sum of the squares of the vertical deviations from each data point to the line (if a point lies on the fitted line exactly, then its vertical deviation is 0 ). Because the deviations are first squared, then summed, there are no cancellations between positive and negative values. The least-squares estimates $b_{0}, b_{1} \ldots b_{n}$ are usually computed by statistical software. Regression:

$$
\begin{aligned}
& \mathrm{Y}=\beta_{0}+\beta_{1} X_{1}+\beta_{2} X_{2}+\beta_{3} \mathrm{X}_{3}+\beta_{4} \mathrm{X}_{4} \\
& \mathrm{Y} \text { : The competitive advantages of } \\
& \mathrm{X}_{1} \text { : Strengths; } \\
& \mathrm{X}_{2} \text { : Opportunities; } \\
& \mathrm{X}_{3} \text { : Threats and } \\
& \mathrm{X}_{4} \text { : Weaknesses }
\end{aligned}
$$$$
Y \text { : The competitive advantages of Vietnam footwear industry }
$$

In this research, I had used the confident level of $95 \%$ (Significance $=0.05$, t-test) for confidence interval.

\section{Research Results}

Descriptive Statistics for factors affecting the competitive advantages of Vietnam footwear industry

Table 1. Questions for factors affecting the competitive advantages of Vietnam footwear industry

\begin{tabular}{lc}
\hline 1. OPPORTUNITY (O) & $\begin{array}{c}\text { Level of } \\
\text { Agreement }\end{array}$ \\
\hline O1. Political instability of Vietnam is good and many young people & 12345 \\
\hline O2. Gross Domestic Product (GDP) growing high each year & 12345 \\
\hline O3. Low inflation (CPI) and low interest rate of the bank & 12345 \\
\hline O4. Increasing export and TPP, ASEAN and income per person increasing & 12345 \\
\hline O5. Globalization and restructuring of the financial system & 12345 \\
\hline O6. Increasing demand for short life cycle fashion footwear & 12345 \\
\hline 2. THREAT (T) & $\begin{array}{c}\text { Level of } \\
\text { Agreement }\end{array}$ \\
\hline $\begin{array}{l}\text { T1. Customers complained about the quality of service and product quality anh increasing } \\
\text { FDI into Vietnam leading to higher competition }\end{array}$ & 12345 \\
\hline
\end{tabular}


T2. Young Entrepreneur culture and social responsibility of enterprises is not high and quality to meet the increasing demands of consumers

T4. The quality of human resources of enterprises is still low

T5. Trade promotion activities and trade connections of enterprises is still limited

W1. Vietnamese footwear products see little value-addition, experts said, noting that their competitive advantages in terms of prices over rivals like China

W2. Some enterprises are not well promoted the role and responsibilities of joining the Union leadership

W3. Dependence on imported materials, machines and equipments

W4. Underdeveloped R\&D and Shortage of human resources with high skills of management and technique

\section{STRENGHTS (S)}

S1. Footwear firms should research the market and expand distribution networks now pushing on the competitive advantages of Vietnam footwear industry

S2. The establishment of Union institutions, the youth union (youth) is the response members on the competitive advantages of Vietnam footwear industry

S3. Fostering human resources for cultural life business on the competitive advantages of Vietnam footwear industry

S4. Promoting the strengths of the organization are linked entrepreneurs, businesses nationwide, has a network spread across the country on the competitive advantages of Vietnam footwear industry

S5. Footwear enterprises continue to focus on brand promotion activities, the members of the business on the competitive advantages of Vietnam footwear industry

S6. Footwear enterprises has nearly 1,000 members to participate in activities. Member businesses are creating jobs for over 1.0 million workers on the competitive advantages of Vietnam footwear industry

\section{Internal - External factors (IEF)}

IEF1: You are completely to be the internal factors on the competitive advantages of Vietnam footwear industry

IEF2: You are completely to be the external factors on the competitive advantages of Vietnam footwear industry

Source: The researcher's collecting data and SPSS

Table 1 showed there were 23 questions for the factor affecting the competitive advantages of Vietnam footwear industry.

\section{1: Strongly disagree; 2: Disagree; 3: Normal; 4: Agree and 5: Strongly agree}

Descriptive statistics is the discipline of quantitatively describing the main features of a collection of information, or the quantitative description itself. Descriptive statistics are distinguished from inferential statistics (or inductive statistics), in that descriptive statistics aim to summarize a sample, rather than use the data to learn about the population that the sample of data is thought to represent. We can see the results following: 
Table 2. Descriptive Statistics for factor affecting the competitive advantages of Vietnam footwear industry

Descriptive Statistics

\begin{tabular}{cccccc}
\hline Code & $\mathrm{N}$ & Minimum & Maximum & Mean & Std. Deviation \\
\hline T1 & 458 & 1 & 5 & 2.93 & 1.580 \\
T2 & 458 & 1 & 5 & 2.82 & 1.462 \\
T3 & 458 & 1 & 5 & 3.02 & .886 \\
T4 & 458 & 1 & 5 & 2.98 & 1.572 \\
T5 & 458 & 1 & 5 & 2.88 & 1.455 \\
O1 & 458 & 1 & 5 & 3.15 & .935 \\
O2 & 458 & 1 & 5 & 3.17 & .929 \\
O3 & 458 & 1 & 5 & 3.28 & .962 \\
O4 & 458 & 1 & 5 & 3.35 & .925 \\
O5 & 458 & 1 & 5 & 3.30 & .917 \\
O6 & 458 & 1 & 5 & 3.27 & .922 \\
W1 & 458 & 1 & 5 & 3.47 & .885 \\
W2 & 458 & 1 & 5 & 3.57 & .922 \\
W3 & 458 & 1 & 5 & 3.47 & .936 \\
W4 & 458 & 1 & 5 & 3.44 & .893 \\
S1 & 458 & 2 & 5 & 3.99 & .949 \\
S2 & 458 & 2 & 5 & 3.94 & .967 \\
S3 & 458 & 1 & 5 & 3.39 & 1.092 \\
S4 & 458 & 2 & 5 & 3.67 & 1.291 \\
S5 & 458 & 1 & 5 & 3.36 & 1.333 \\
S6 & 458 & 1 & 5 & 3.97 & .967 \\
IEF1 & 458 & 2 & 5 & 3.37 & .567 \\
IEF2 & 458 & 1 & 5 & 2.38 & .580 \\
Valid N (listwise) & 458 & & & & \\
\hline
\end{tabular}

Source: The researcher's collecting data and SPSS

Table 2 showed that there were 500footwear enterprisesinterviewed from 11/2014 to 12/2015. There were 458enterprises processed. The results showed that max value is 5, minimum is 1 , mean is around 3.0 and Std. Deviation is around 1.0.

Testing the reliability of the scale for factor affecting the competitive advantages of Vietnam footwear industry

Table 3. Results of analysis of Cronbach Alpha coefficients

\begin{tabular}{|c|c|c|c|c|c|}
\hline \multicolumn{2}{|l|}{ Indicators } & \multirow{2}{*}{$\begin{array}{c}\text { Average scale if } \\
\text { removal } \\
\text { variables }\end{array}$} & \multirow{2}{*}{$\begin{array}{c}\text { Scale variance if } \\
\text { the removal } \\
\text { variables }\end{array}$} & \multirow[t]{2}{*}{$\begin{array}{c}\text { The } \\
\text { correlation } \\
\text { coefficient of } \\
\text { the total } \\
\text { variations } \\
.790\end{array}$} & \multirow{2}{*}{$\begin{array}{c}\text { Cronbach alpha } \\
\text { coefficient if the } \\
\text { removal } \\
\text { variables }\end{array}$} \\
\hline \multirow{6}{*}{ Opportunities (O) } & O1 & & & & \\
\hline & $\mathrm{O} 2$ & 16.34 & 15.854 & .721 & .907 \\
\hline & $\mathrm{O} 3$ & 16.24 & 15.365 & .764 & .902 \\
\hline & $\mathrm{O} 4$ & 16.16 & 15.930 & .714 & .908 \\
\hline & O5 & 16.22 & 15.413 & .806 & .896 \\
\hline & O6 & 16.24 & 15.485 & .789 & .898 \\
\hline \multicolumn{6}{|c|}{ CronbachAlpha $=0.917$} \\
\hline Threats (T) & $\mathrm{T} 1$ & 11.70 & 22.881 & .905 & .896 \\
\hline
\end{tabular}




\begin{tabular}{|c|c|c|c|c|c|}
\hline & $\mathrm{T} 2$ & 11.80 & 24.505 & .858 & .905 \\
\hline & T3 & 11.61 & 32.392 & .584 & .954 \\
\hline & $\mathrm{T} 4$ & 11.65 & 22.934 & .907 & .895 \\
\hline & T5 & 11.74 & 24.498 & .864 & .904 \\
\hline \multicolumn{6}{|c|}{ CronbachAlpha $=0.930$} \\
\hline \multirow{6}{*}{ Strengths (S) } & S1 & 18.33 & 25.746 & .939 & .934 \\
\hline & $\mathrm{S} 2$ & 18.38 & 25.921 & .897 & .938 \\
\hline & S3 & 18.93 & 26.001 & .763 & .951 \\
\hline & $\mathrm{S} 4$ & 18.66 & 23.566 & .834 & .945 \\
\hline & S5 & 18.96 & 23.092 & .845 & .945 \\
\hline & S6 & 18.35 & 25.856 & .905 & .937 \\
\hline \multicolumn{6}{|c|}{ CronbachAlpha $=0.951$} \\
\hline \multirow{4}{*}{ Weaknesses (W) } & W1 & 10.47 & 5.834 & .807 & .851 \\
\hline & W2 & 10.38 & 5.790 & .773 & .863 \\
\hline & W3 & 10.48 & 5.878 & .731 & .879 \\
\hline & W4 & 10.51 & 5.944 & .764 & .867 \\
\hline
\end{tabular}

Source: The researcher's collecting data and SPSS

The Table 3 revealed that all of components of Cronbach Alpha are very high 0.6. Besides, Cronbach alpha coefficient if the removal variables are very high 0.6. The table 3 revealed that theyhave been proposed that alpha can be viewed as the expected correlation of two tests that measure the same construct. By using this definition, it is implicitly assumed that the average correlation of a set of items is an accurate estimate of the average correlation of all items that pertain to a certain construct. Cronbach's alpha is a function of the number of items in a test, the average covariance between item-pairs, and the variance of the total score. The table 3 revealed that all of components are very good for this research. Continue author analyzed the EFA to assess more accurately the scale, helping the uniform scale in research. Thus, based on the authors EFA analysis will evaluate the homogeneity of the observed variables and can be classified because of specific variables. Besides, Cronbach alpha coefficient if the removal variables is more than 0.6. In addition, the correlation coefficient of the total variations is more than 0.3. Alpha may be seen to be quite complexly determined from this perspective. That is, alpha is sensitive not only to general factor saturation in a scale but also to group factor saturation and even to variance in the scale scores arising from variability in the factor loadings.

KMO and Bartlett's Test for factor affecting the competitive advantages of Vietnam footwear industry. KMO \& Bartlett's Test of Sphericity is a measure of sampling adequacy that recommended checking the case to variable ratio for the analysis conducted. In most academic and business studies, KMO \& Bartlett's test play an important role for accepting the sample adequacy. While the KMO ranges from 0 to 1 , the world-over accepted index is over 0.6. The Bartlett's Test of Sphericity must be less than 0.05 .

Table 4. KMO and Bartlett's Test for factor affecting the competitive advantages of Vietnam footwear industry

KMO and Bartlett's Test

\begin{tabular}{llc}
\hline Kaiser-Meyer-Olkin Measure of Sampling Adequacy. & .764 \\
& Approx. Chi-Square & 12739.234 \\
Bartlett's Test of Sphericity & df & 210 \\
\cline { 2 - 3 } & Sig. & .000 \\
\hline
\end{tabular}


Total Variance Explained

\begin{tabular}{|c|c|c|c|c|c|c|c|}
\hline \multirow{2}{*}{ Com. } & \multicolumn{3}{|c|}{ Initial Eigenvalues } & \multicolumn{3}{|c|}{ Extraction Sums of Squared Loadings } & \multirow{2}{*}{$\begin{array}{c}\text { Rotation Sums of } \\
\begin{array}{c}\text { Squared } \\
\text { Loadings }^{\mathrm{a}}\end{array} \\
\text { Total }\end{array}$} \\
\hline & Total & $\begin{array}{c}\% \text { of } \\
\text { Variance } \\
\end{array}$ & $\begin{array}{c}\text { Cumulative } \\
\%\end{array}$ & Total & $\begin{array}{c}\% \text { of } \\
\text { Variance } \\
\end{array}$ & $\begin{array}{c}\text { Cumulative } \\
\%\end{array}$ & \\
\hline 1 & 6.721 & 32.005 & 32.005 & 6.721 & 32.005 & 32.005 & 5.145 \\
\hline 2 & 4.822 & 22.960 & 54.965 & 4.822 & 22.960 & 54.965 & 5.396 \\
\hline 3 & 3.494 & 16.638 & 71.604 & 3.494 & 16.638 & 71.604 & 4.200 \\
\hline 4 & 1.412 & 6.725 & 78.329 & 1.412 & 6.725 & 78.329 & 5.101 \\
\hline 5 & .806 & 3.839 & 82.168 & & & & \\
\hline 6 & .684 & 3.257 & 85.425 & & & & \\
\hline 7 & .654 & 3.113 & 88.538 & & & & \\
\hline 8 & .507 & 2.413 & 90.951 & & & & \\
\hline 9 & .381 & 1.814 & 92.766 & & & & \\
\hline 10 & .320 & 1.524 & 94.290 & & & & \\
\hline 11 & .304 & 1.447 & 95.737 & & & & \\
\hline 12 & .240 & 1.143 & 96.880 & & & & \\
\hline 13 & .176 & .838 & 97.718 & & & & \\
\hline 14 & .126 & .601 & 98.320 & & & & \\
\hline 15 & .084 & .401 & 98.721 & & & & \\
\hline 16 & .074 & .353 & 99.074 & & & & \\
\hline 17 & .067 & .317 & 99.391 & & & & \\
\hline 18 & .052 & .249 & 99.640 & & & & \\
\hline 19 & .051 & .245 & 99.885 & & & & \\
\hline 20 & .021 & .098 & 99.983 & & & & \\
\hline 21 & .004 & .017 & 100.000 & & & & \\
\hline
\end{tabular}

Source: The researcher's collecting data and SPSS

Table 4 showed that Kaiser-Meyer-Olkin Measure of Sampling Adequacy was statistically significantandhigh datareliability $(\mathrm{KMO}=0.764>0.6)$. This result was very good for data analysis. Table 4 showed that Cumulative percent was statistically significantandhigh datareliabilitywas $78.329 \%$ (> $60 \%)$. This Data is very good for the next analysis of Structure Matrix for factor affecting the competitive advantages of Vietnam footwear industry following. Structure Matrix for factor affecting the competitive advantages of Vietnam footwear industry

Table 5. Structure Matrix for factor affecting the competitive advantages of Vietnam footwear industry

\begin{tabular}{ccccc}
\hline \multirow{2}{*}{ Code } & \multicolumn{4}{c}{ Component } \\
\cline { 2 - 4 } S1 & 1 & 2 & 3 & 4 \\
\hline S2 & .967 & & & \\
S6 & .944 & & & \\
S5 & .943 & & & \\
S4 & .884 & & & \\
S3 & .868 & & & \\
O2 & .843 & & & \\
O1 & & .988 & & \\
O6 & & .982 & & \\
O5 & & .761 & \\
O3 & & .750 & \\
O4 & & .583 &
\end{tabular}




\begin{tabular}{ccc} 
T4 & .938 & \\
T1 & .935 & \\
T5 & .911 & \\
T2 & .905 & \\
T3 & .695 & \\
W3 & & .952 \\
W2 & & .923 \\
W1 & & .776 \\
W4 & & .766 \\
\hline
\end{tabular}

Source: The researcher's collecting data and SPSS

Table 5 showed that Structure Matrix for factor affecting the competitive advantages of Vietnam footwear industryhad fourcomponents. Component 1 was Strengths(X1), Component 2 was Opportunities (X2), Component 3 was Threats (X3) and Component 4 is Weaknesses(X4) affecting the competitive advantages of Vietnam footwear industry of provinces in Vietnam. We can call Y: the competitive advantage of Vietnam footwear industry. Y can call dependent variable. The researcher continues the KMO and Bartlett's Test for the competitive advantages of Vietnam footwear industry (Y: dependent variable) following:

$\mathrm{KMO}$ and Bartlett's Test for thecompetitive advantages of Vietnam footwear industry (Y: dependent variable)

Table 6. KMO and Bartlett's Test for the competitive advantages of Vietnam footwear industry

\begin{tabular}{llc}
\multicolumn{2}{c}{ KMO and Bartlett's Test } \\
\hline Kaiser-Meyer-Olkin Measure of Sampling Adequacy. & .500 \\
& Approx. Chi-Square & 1562.488 \\
Bartlett's Test of Sphericity & df & 1 \\
& Sig. & .000 \\
\hline
\end{tabular}

Total Variance Explained

\begin{tabular}{ccccccc}
\hline \multirow{2}{*}{ Comp. } & \multicolumn{5}{c}{ Initial Eigenvalues } & \multicolumn{3}{c}{ Extraction Sums of Squared Loadings } \\
\cline { 2 - 6 } & Total & \% of Variance & Cumulative \% & Total & \% of Variance & Cumulative \% \\
\hline 1 & 1.984 & 99.184 & 99.184 & 1.984 & 99.184 & 99.184 \\
2 & .016 & .816 & 100.000 & & & \\
\hline
\end{tabular}

Source: The researcher's collecting data and SPSS

Table 6 showed that KMO and Bartlett's Test for the competitive advantages of Vietnam footwear industryshowed that Kaiser-Meyer-Olkin Measure of Sampling Adequacy was statistically significantandhigh datareliability (KMO = 0.500 ). This result was very good for data analysis. The competitive advantages of Vietnam footwear industry (Y: dependent variable)showed that Cumulative percent was statistically significantandhigh datareliabilitywas $99.184 \%$ $(>60 \%)$.

Table 7. KMO and Bartlett's Test for factors affecting the competitive advantages of Vietnam footwear industry

\begin{tabular}{llccc}
\hline \multirow{2}{*}{ Indicators } & Items & KMO & $\begin{array}{c}\text { Extraction Sums of } \\
\text { Squared Loadings }\end{array}$ \\
\hline \multirow{3}{*}{ Independent } & Threats (T) & 5 & 0.520 & 78.457 \\
\cline { 2 - 5 } & Opportunities (O) & 6 & 0.775 & 70.675 \\
\cline { 2 - 5 } & Strengths (S) & 6 & 0.881 & 82.718 \\
\cline { 2 - 5 } & Weaknesses (W) & 4 & 0.687 & 76.238 \\
\hline Dependent & Internal - External factors (IEF) & 2 & 0.500 & 99.184 \\
\hline
\end{tabular}

Source: The researcher's collecting data and SPSS 
The Table 7 showed that the resultswere very good for data analysis. The competitive advantages of Vietnam footwear industryshowed that Cumulative percent was statistically significant and high data reliability and KMO and Bartlett's Test was over 0.500. Besides, Extraction Sums of Squared Loadings of Variance is very high ( $>60 \%)$. In addition, the multivariate analysis, one goal is to explain why observations, in this case people, have different answers on your survey. Factor analysis groups survey questions that vary together. This makes it easier to model in a regression or ANOVA because it reduces a large number of variables (i.e., survey items) into a smaller set of factors. Each factor explains a percent of the total variance. Factors that do not explain much variance might not be worth including in the final model. It takes some iteration to come up with the optimal number of factors. I took a look at your output with regard to explained variance, and it appears that the unroasted solution would support a single factor solution, since the amount of explained variance drops sharply after the first factor (which is known as a "scree" plot to assessing the of factors). If that is the case, then you will have relatively strong loadings ( 0.4 or higher) on each of the variables for the first factor, and relatively small loadings on all the other factors.

Table 8. Regression Model Summary analysis the factors affecting the competitive advantages of Vietnam footwear industry

\begin{tabular}{|c|c|c|c|c|c|c|c|}
\hline \multicolumn{7}{|c|}{ Model Summary $^{\text {b }}$} & \\
\hline Model & $\mathrm{R}$ & R Square & $\begin{array}{r}\text { Adj } \\
\text { S }\end{array}$ & usted R & $\begin{array}{l}\text { Std. Error of the } \\
\text { Estimate }\end{array}$ & Durbin-Watson & \\
\hline 1 & .838 & .703 & & 700 & .54737034 & 2.068 & \\
\hline \multirow{2}{*}{\multicolumn{8}{|c|}{ a. Predictors: (Constant), X4, X2, X1, X3 }} \\
\hline & & & & & & & \\
\hline \multicolumn{2}{|r|}{ Model } & \multicolumn{2}{|c|}{ Sum of Squares } & $\mathrm{df}$ & Mean Square & $\mathrm{F}$ & Sig. \\
\hline \multirow{3}{*}{1} & Regression & 321. & & 4 & 80.319 & 268.074 & .000 \\
\hline & Residual & 135 . & & 453 & .300 & & \\
\hline & Total & 457. & & 457 & & & \\
\hline
\end{tabular}

a. Dependent Variable: Y

b. Predictors: (Constant), X4, X2, X1, X3

\section{Coefficients $^{\mathrm{a}}$}

\begin{tabular}{ccccccccc}
\hline \multirow{2}{*}{ Model } & \multicolumn{2}{c}{ Unstandardized Coefficients } & $\begin{array}{c}\text { Standardized } \\
\text { Coefficients }\end{array}$ & \multirow{2}{*}{$\mathrm{t}$} & Sig. & \multicolumn{2}{c}{ Collinearity Statistics } \\
\cline { 2 - 3 } & $\mathrm{B}$ & Std. Error & Beta & & & & Tolerance & VIF \\
\hline (Constant) & $-1.736 \mathrm{E}-016$ & .026 & & .000 & 1.000 & & \\
\hline $\mathrm{X} 1(\mathrm{~S})$ & .449 & .026 & .449 & 17.220 & .000 & .966 & 1.035 \\
\hline $\mathrm{X} 2(\mathrm{O})$ & .390 & .032 & .390 & 12.298 & .000 & .652 & 1.533 \\
\hline $\mathrm{X} 3(\mathrm{~T})$ & .363 & .026 & .363 & 13.866 & .000 & .957 & 1.045 \\
\hline $\mathrm{X} 4(\mathrm{~W})$ & .358 & .032 & .358 & 11.311 & .000 & .655 & 1.526 \\
\hline
\end{tabular}

a. Dependent Variable: Y: the competitive advantages of Vietnam footwear industry

Source: The researcher's collecting data and SPSS

Table 8 showed that Adjusted R Square was statistically significant and high data reliability. In addition, Adjusted R Square reached $70.0 \%$. The results showed that all $\mathrm{t}$ value $>2$ was statistically significant and high data reliability. Besides, the regression coefficients were positive. This showed that the effects of independent variables in the same direction with the competitive advantages of Vietnam footwear industry with significance level of 5\%.

Table 8 showed thatVariance Inflation Factor (VIF) and Tolerance are two measures that can guide aresearcher in identifying MC. Before developing the concepts, it should be noted that thevariance of the OLS estimator for a typical regression coefficient shownto be the following VIF $<10(1<\mathrm{VIF}<10)$. This showed that there was not Multicollinearity. 


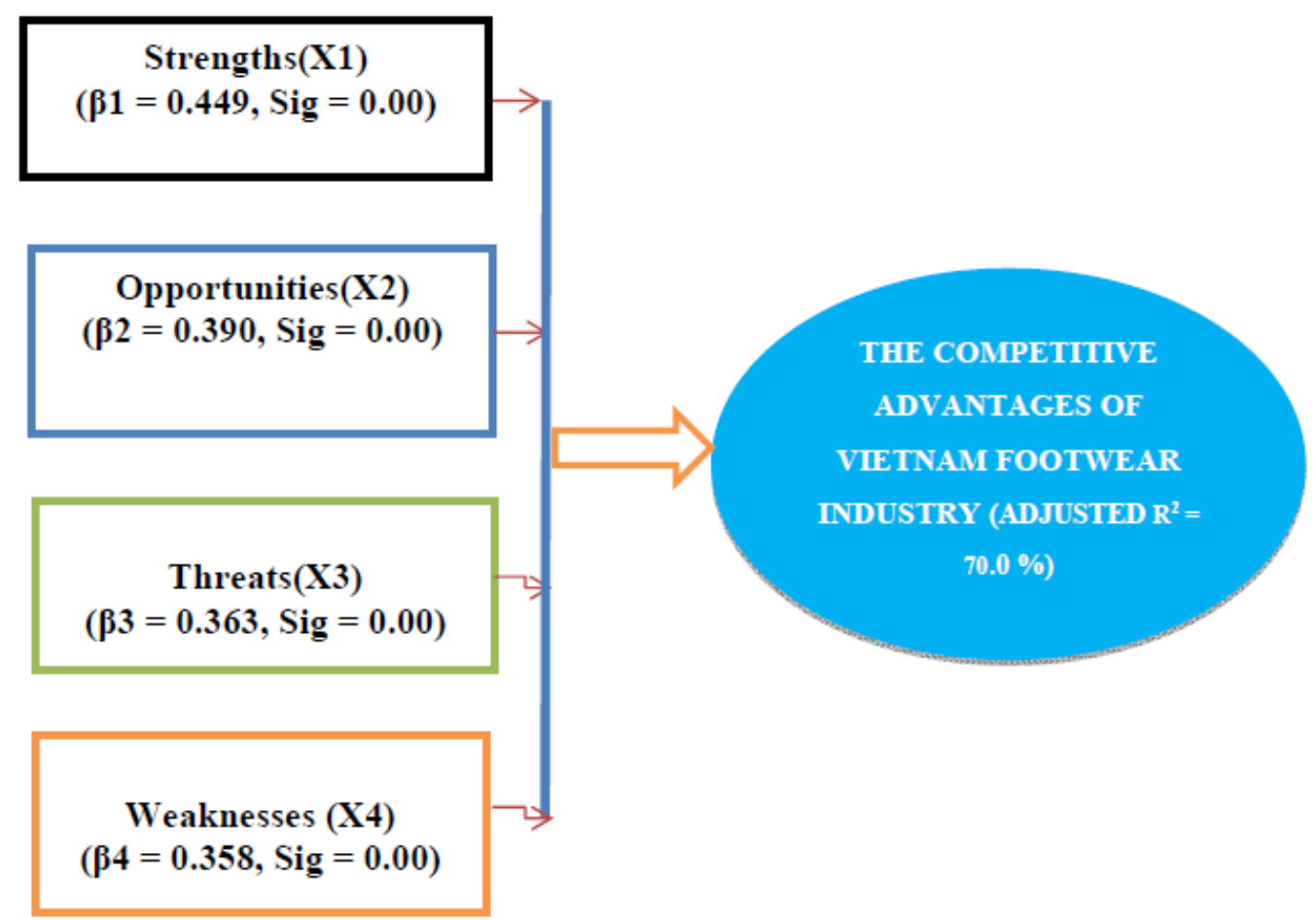

Figure 2. The Result of the Regressionforthe factors affecting the competitive advantages of Vietnam footwear industry

Figure 2 showed that theregression coefficientswere positive. This showed thattheeffectsof independent variables are in the same directionto the competitive advantages of Vietnam footwear industrywith significancelevel of $5 \%$. Component 1(X1): Strength factor affected the competitive advantages of Vietnam footwear industry with significance level of 5\%. Component 2(X2): Opportunityfactor affected the competitive advantages of Vietnam footwear industry with significance level of $5 \%$. Component $3(\mathrm{X} 3)$ : Threat factor affected the competitive advantages of Vietnam footwear industry with significance level of 5\%. Component 4(X4): Weakness factor affected the competitive advantages of Vietnam footwear industrywith significance level of 5\%.

The Result of the Regression Standardized Residual for the competitive advantage of Vietnam footwear industry

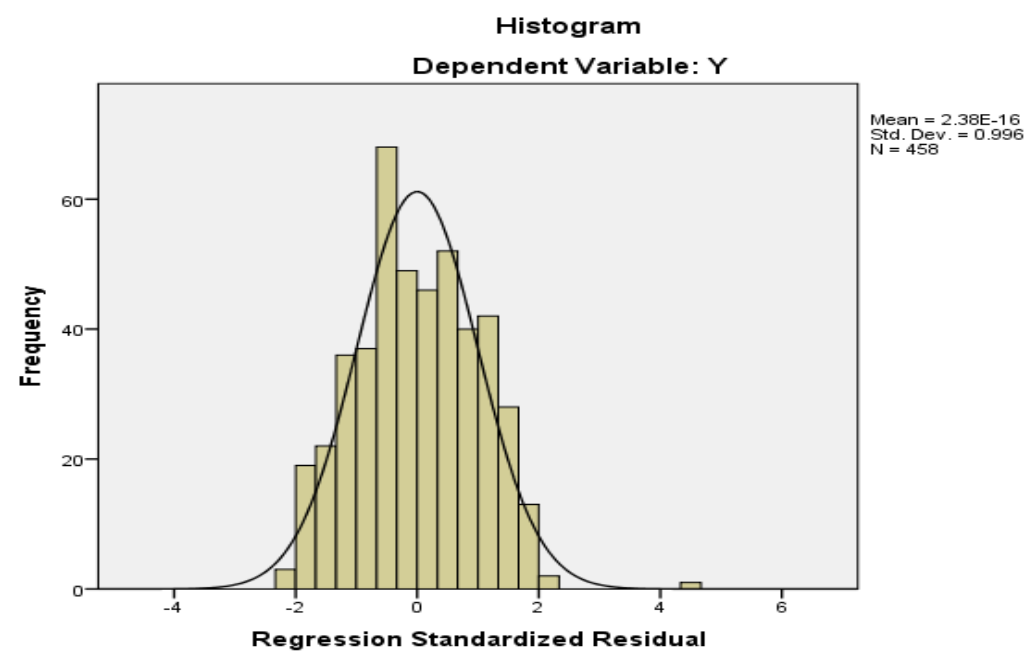




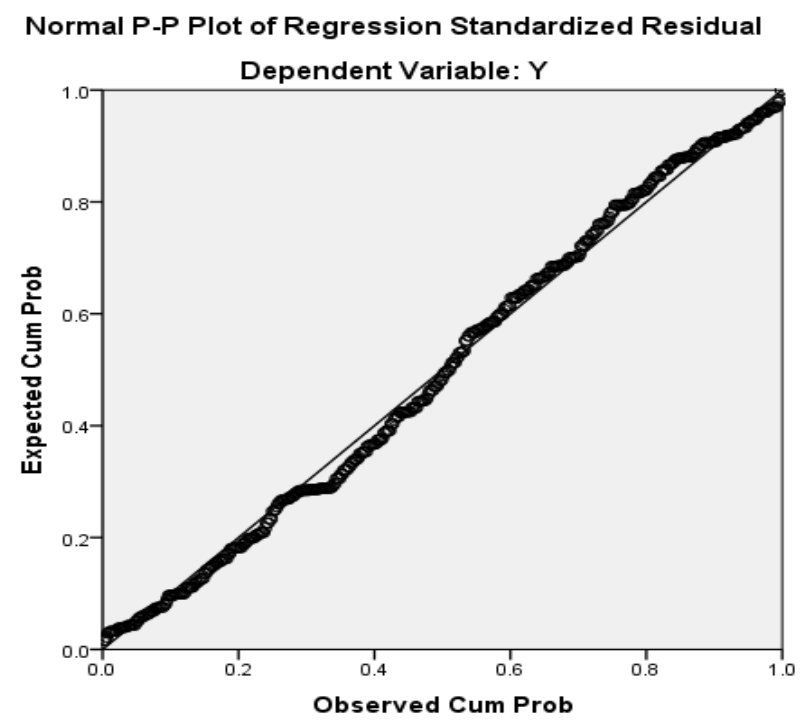

Figure 3. The RESULT OF THE REGRESSION STANDARDIZED RESIDUAL

Source: The researcher's collecting data and SPSS

Figure 3 showed that the standardized residual of the competitive advantages of Vietnam footwear industrywas normal distribution (Standard deviation $=0.996$, nearly $=1$ ).

Table 9. Bootstrap results based on 1000 bootstrap for the competitive advantages of Vietnam footwear industry

Bootstrap for Model Summary

\begin{tabular}{lccccc}
\hline \multirow{2}{*}{ Model } & Durbin-Watson & \multicolumn{4}{c}{ Bootstrap $^{\mathrm{a}}$} \\
\cline { 3 - 6 } & & \multirow{2}{*}{ Bias } & \multirow{2}{*}{ Std. Error } & \multicolumn{3}{c}{$95 \%$ Confidence Interval } \\
\cline { 3 - 6 } & 2.068 & -.758 & .086 & Lower & Upper \\
\hline 1 & &
\end{tabular}

a. Unless otherwise noted, bootstrap results are based on 1000 bootstrap samples

Bootstrap for Coefficients

\begin{tabular}{ccccccc}
\hline \multirow{2}{*}{ Model } & \multirow{6}{*}{ Bootstrap $^{\mathrm{a}}$} \\
\cline { 6 - 7 } & & \multirow{2}{*}{ Bias } & Std. Error & $\begin{array}{c}\text { Sig. } \\
(2-t a i l e d)\end{array}$ & \multicolumn{2}{c}{$95 \%$ Confidence Interval } \\
\cline { 6 - 7 } (Constant) & $-1.736 \mathrm{E}-016$ & .000 & .025 & 1.000 & -.051 & .050 \\
X1 & .449 & .001 & .027 & .001 & .394 & .504 \\
X2 & .390 & $-4.445 \mathrm{E}-005$ & .028 & .001 & .335 & .445 \\
X3 & .363 & .001 & .027 & .001 & .311 & .419 \\
X4 & .358 & .001 & .029 & .001 & .303 & .412 \\
\hline
\end{tabular}

a. Unless otherwise noted, bootstrap results are based on 1000 bootstrap samples

Source: The researcher's collecting data and SPSS

Table 9 showed that Bootstrap is an alternative to asymptotic approximation for carrying out inference. This showed that there were the same results of the regression for the competitive advantages of Vietnam footwear industry. Besides, table 10 showed that Bootstrap for Coefficients of bias is very small, nearly 0.00 .

Testing correlation for components and the competitive advantages of Vietnam footwear industry 
Table 10. Testing correlation between components and the competitive advantages of Vietnam footwear industry

\section{Correlations}

\begin{tabular}{llccccc}
\hline & \multicolumn{1}{c}{ Variables } & $\mathrm{Y}$ & $\mathrm{X} 1$ & $\mathrm{X} 2$ & $\mathrm{X} 3$ & $\mathrm{X} 4$ \\
\hline \multirow{3}{*}{ Y } & Pearson Correlation & 1 & $.440^{* *}$ & $.514^{* *}$ & $.346^{* *}$ & $.502^{* *}$ \\
& Sig. (2-tailed) & & .000 & .000 & .000 & .000 \\
& $\mathrm{~N}$ & 458 & 458 & 458 & 458 & 458 \\
& Pearson Correlation & $.440^{* *}$ & 1 & -.078 & $.163^{* *}$ & $-.104^{*}$ \\
$\mathrm{X} 1$ & Sig. (2-tailed) & .000 & & .097 & .000 & .026 \\
& $\mathrm{~N}$ & 458 & 458 & 458 & 458 & 458 \\
& Pearson Correlation & $.514^{* *}$ & -.078 & 1 & $-.138^{* *}$ & $.584^{* *}$ \\
$\mathrm{X} 2$ & Sig. (2-tailed) & .000 & .097 & & .003 & .000 \\
& N & 458 & 458 & 458 & 458 & 458 \\
& Pearson Correlation & $.346^{* *}$ & $.163^{* *}$ & $-.138^{* *}$ & 1 & $-.101^{*}$ \\
X3 & Sig. (2-tailed) & .000 & .000 & .003 & & .031 \\
& N & $458 *$ & 458 & 458 & 458 & 458 \\
& Pearson Correlation & $.502^{* *}$ & $-.104^{*}$ & $.584^{* *}$ & $-.101^{*}$ & 1 \\
X4 & Sig. (2-tailed) & .000 & .026 & .000 & .031 & \\
& N & 458 & 458 & 458 & 458 & 458 \\
\hline
\end{tabular}

**. Correlation is significant at the 0.01 level (2-tailed).

*. Correlation is significant at the 0.05 level (2-tailed).

Source: The researcher's collecting data and SPSS

Table 11 showed that testing correlation between components and the competitive advantages of Vietnam footwear industryshowed that there wasPearson correlation.Correlation is significant at the 0.05 level (2-tailed).

Analysis of Variance (ANOVA) about the competitive advantages of Vietnam footwear industry

Table 11. Analysis of Variance (ANOVA) about gender

\begin{tabular}{lccccc}
\hline \multicolumn{1}{c}{ Gender } & Sum of Squares & df & Mean Square & F & Sig. \\
\hline Between Groups & 1.643 & 1 & 1.643 & 1.645 & .200 \\
Within Groups & 455.357 & 456 & .999 & & \\
Total & 457.000 & 457 & & & \\
\hline
\end{tabular}

Source: The researcher's collecting data and SPSS

Table 11 showed that Analysis of Variance (ANOVA) about Gendershowed that $\mathrm{F}=1.645$ was statistically significant and Significance valuewas 0.200(> 0.05). Therefore,we reject $\mathrm{H}_{1}$ and accept $\mathrm{H}_{0}$. This showed that there was no different from Genderfor the assessment of the competitive advantages of Vietnam footwear industrywith significance level of $5 \%$.

Table 12. Analysis of Variance (ANOVA) about family situation

\begin{tabular}{lccccc}
\hline \multicolumn{1}{c}{ Family situation } & Sum of Squares & $\mathrm{df}$ & Mean Square & F & Sig. \\
\hline Between Groups & 1.944 & 1 & 1.944 & 1.948 & .163 \\
Within Groups & 455.056 & 456 & .998 & & \\
Total & 457.000 & 457 & & & \\
\hline
\end{tabular}

Source: The researcher's collecting data and SPSS

Table 12 showed that Analysis of Variance (ANOVA) about Family situation showed that $\mathrm{F}=1.948$ was statistically significant and Significance valuewas 0.163(>0.05). Therefore,we reject $\mathrm{H}_{1}$ and accept $\mathrm{H}_{0}$. This showed that there was no different from Family situation for the assessment of the competitive advantages of Vietnam footwear industrywith significance level of $5 \%$. 
Table 13. Analysis of Variance (ANOVA) about the level of the knowledge

\begin{tabular}{lccccc}
\hline \multicolumn{1}{c}{$\begin{array}{c}\text { The level of the } \\
\text { knowledge }\end{array}$} & Sum of Squares & df & Mean Square & F & Sig. \\
\hline Between Groups & 2.555 & 2 & 1.277 & 1.279 & .279 \\
Within Groups & 454.445 & 455 & .999 & & \\
Total & 457.000 & 457 & & & \\
\hline
\end{tabular}

Source: The researcher's collecting data and SPSS

Table 13 showed that Analysis of Variance (ANOVA) about the level of the knowledgeshowed that $\mathrm{F}=1.279$ was statistically significant and Significance valuewas $0.279(>0.05)$. Therefore,we reject $\mathrm{H}_{1}$ and accept $\mathrm{H}_{0}$. This showed that there was no different from the level of the knowledgefor the assessment of the competitive advantages of Vietnam footwear industrywith significance level of $5 \%$.

Table 14. Analysis of Variance (ANOVA) about the experiences for working

\begin{tabular}{lccccc}
\hline \multicolumn{1}{c}{ Experienced } & Sum of Squares & df & Mean Square & F & Sig. \\
\hline Between Groups & 2.740 & 2 & 1.370 & 1.372 & .255 \\
Within Groups & 454.260 & 455 & .998 & & \\
Total & 457.000 & 457 & & & \\
\hline
\end{tabular}

Source: The researcher's collecting data and SPSS

Table 14 showed that Analysis of Variance (ANOVA) about the experiences for working showed that $\mathrm{F}=1.372$ was statistically significant and Significance valuewas $0.255(>0.05)$. Therefore,we reject $\mathrm{H}_{1}$ and accept $\mathrm{H}_{0}$. This showed that there was no different from experiencesfor the assessment of the competitive advantages of Vietnam footwear industrywith significance level of $5 \%$.

Table 15. Analysis of Variance (ANOVA) about income

\begin{tabular}{lccccc}
\hline \multicolumn{1}{c}{ Income } & Sum of Squares & df & Mean Square & F & Sig. \\
\hline Between Groups & .435 & 2 & .217 & .217 & .805 \\
Within Groups & 456.565 & 455 & 1.003 & & \\
Total & 457.000 & 457 & & & \\
\hline
\end{tabular}

Source: The researcher's collecting data and SPSS

Table 15 showed that Analysis of Variance (ANOVA) about Incomeshowed that $F=0.217$ was statistically significant and Significance valuewas 0.805( $>0.05)$. Therefore,we reject $\mathrm{H}_{1}$ and accept $\mathrm{H}_{0}$. This showed that there was no different from incomefor the assessment of the competitive advantages of Vietnam footwear industrywith significance level of $5 \%$.

\section{Conclusions}

This research conducted during the period from January 2014 to January 2016. The research result showed that there were 500 enterprises related footwear but 458 processed and 42 missed. Besides, all of enterprises interviewed and answered nearly 23 questions. The researcher had analyzed KMO test, the result of KMO analysis used for multiple regression analysis. The enterprise responses measured through an adapted questionnaire on a 5-point Likert scale. Hard copy and interview enterprise by questionnaire distributed among enterprises of the provinces of Vietnam.

The regression analysis results showed that there were four factors, which included of factors following: strengths (S); Opportunity (O); Threat (T) and weakness (W)actually affected the competitive advantages of Vietnam footwear industry with $5 \%$ significance level. The main objectives of this study were following:

1. The researcher had been conducted a survey to find factors that affecting the competitive advantages of Vietnam footwear industry.

2. The researcher had been identified some factors that affecting the competitive advantages of Vietnam footwear industry.

3. The researcher had been analyzed and to test some factors that affecting the competitive advantages of Vietnam footwear industry. 
4. Finally, I recommended solutions to improve the competitive advantages of Vietnam footwear industry.

This research finds out some factors that affecting the competitive advantages of Vietnam footwear industry: First of all, Component 1 (X1): Strength factor affected the competitive advantages of Vietnam footwear industry with significance level of five percent. Second, component 2 (X2): Opportunity factor affected the competitive advantages of Vietnam footwear industry with significance level of five percent. Third, component 3 (X3): Threat factor affected the competitive advantages of Vietnam footwear industry with significance level of five percent. Finally, Component 4 (X4): Weakness factor affected the competitive advantages of Vietnam footwear industry with significance level of five percent.

The Government of Vietnam has actively negotiated FTAs with countries with strong impacts on the footwear sector development. Typical pacts are the Trans-Pacific Partnership (TPP) with 12 Asia - Pacific countries, the FTA with the EU (FTAEV), the FTA with Customs Union of Russia - Belarus - Kazakhstan, and the ASEAN Economic Community Agreement effective in 2015. When Vietnam joins the TPP, the first plus is the elimination of the current tax rate of 3.5 - 57.4 percent. With zero tax, the leather and footwear sector is expected to make a strong export leap. This is not only seen as a driving force but also a "golden" opportunity for the footwear industry to develop both in quantity and quality.

ASEAN, a group of 10 Southeast Asian nations, inked FTAs with China, Japan, South Korea, India, Australia and New Zealand. ASEAN is also negotiating a common Regional Comprehensive Economic Partnership (RCEP) between ASEAN with and the six above countries, called ASEAN+6, to form a large FTA area consisting of 16 countries with more than 3 billion people. Vietnam will have the opportunity to expand exports to East Asian nations, India and Australia.

Particularly, Vietnam signed an FTA with South Korea on May 5, 2015 and with the Eurasian Economic Union (formerly known as the Customs Union) on May 29, 2015. Signatories are carrying out procedures for the early enforcement of these agreements. Also in the first six months of 2015, Vietnam held talks with other parties to finalize Vietnam - EU FTA and TPP, expected to be signed in 2015.

As FTAs will take effect in the next 1-2 years, they will have no major direct impact on export increase in 2015 but they will create an attractive environment for foreign investors seeking to establish production facilities in Vietnam.

The ASEAN Economic Community (AEC) will be formed on December 31, 2015, making ASEAN an important market with 625 million people. However, Vietnam's footwear exports to ASEAN countries will not increase much because many ASEAN countries are currently strong rivals to Vietnam. Meanwhile, competitive pressures in the domestic market will augment as ASEAN countries will seek to export footwear to Vietnam when import tariffs are made 0.0 percent.

However, the footwear industry of Vietnam must continue to confront many inherent challenges relating to input materials, human resources, product development and business administration. Besides, it will have to prepare for dealing with new challenges arising from FTA requirements.

There are many reasons for the current difficulties of the Vietnam's footwear industry in seeking exports: Outsourcing for export, using input materials offered by foreign contractors, having weak design capacity and weak material production and supply development. Some inputs have not been or little been made in Vietnam, including leatherette, nonwoven fabrics, technical fabrics, insole texon, materials and accessories (in metal and plastic), adhesives and chemicals. The sector can supply less than 20 percent of these items.

Besides, product quality of some businesses disqualified for export. Some companies are qualified for export but they cannot meet delivery requirements.

Moreover, the technological level of Vietnamese footwear industry is limited, resulting in production difficulties. Vietnam has not planned material production development zones like leather, cotton, synthetic fibers and chemicals.

\section{References}

Ajzen, I., \& Fishbein, M. (1980). Understanding attitudes and predicting social behavior. Englewood Cliffs, NJ:Prentice-Hall.

Ary, D., Jacobs, L., Sorensen, C., \& Razavieh, A. (2009). Introduction to research ineducation (8th ed.). Belmont, CA: Wadworth.

Babakus, E., \& Boller, G. W. (1992). An empirical assessment of SERVQUAL scale. University of Missouri, USA.

Barzun, J., \& Graff, H. F. (1987). The Modern Researcher. New York: Harcourt, Brace.

Bateson, J.E.G. (1992). Managing service marketing: Text and reading. Fort Worth: The Dryden Press.

Bell, J. (2005). Doing Your Research Project. Birmingham, Open University Press.

Berg, B. (2001). Qualitative research methods for the social sciences. Boston:Allyn and Bacon. 
Berg, B. L. (2009). Qualitative Research Methods for the Social Sciences. Boston MA: Pearson Education Inc.

Blaug, M. (2007). The Social Sciences: Economics. The New Encyclopædia Britannica.

Brooks, I., \& Jamie Weatherston. (2000). The Business Environment: Challenges and Changes (2nd ed.). Pearson Education Limited, London.

Charles Harvie. (2010). Competition Policy and SMEs in Vietnam. Paper presented at an AusAid-APEC Workshop on Anti-trust Law and Competition Policy. Ministry of Trade, Hanoi, Vietnam.

Cheng, Y. C., \& Tam, M. M. (1997). Multi-Model of quality in education. Quality Assurance in Education.

Creswell, J. (2003). Research Design: Qualitative, Quantitative, and Mixed Methods Approaches. Thousand Oaks, California: Sage Publications.

Crijins, H., \& Ooghi. (2000). Paths of Growth Medium Sized entrepreneurial companies. Voor De Vlerick Management School, University of Ghent.

Dess, G. G., Lumpkin, G.T., Alan, B. Eisner, Gerry McNamara, \& Bongjin Kim. (2012). Strategic Management: Text and Cases. Six Edition (Global Edition). McGraw-Hill Companies, Inc., New York, USA.

DyahRatihSulistyastuti. (2004). Dynamics of Small and Medium Enterprises (SMEs) Analysis of regional concentration of SMEs in Indonesia from 1999 to 2001. Journal of Development Economics.

Engle James F., \& Blackwell Roger D. (1982). Consumer Behavior. Holt, Rinehart and Winston, New York.

Fisher, C. (2004). Researching and Writing a Dissertation for Business Students. Harlow, FT Prentice Hall.

Gorsuch, R. L. (1983). Factor analysis (2nd ed.). Hillsdale. NJ: Erlbaum.

H Gin Chong. (2008).Measuring performance of small-and-medium sized enterprises: the grounded theory approach. Journal Business and Public Affairs.

Hair, J. F., Tatham, R. L., Anderson, R. E., \& Black, W. (1998). Multivariate data analysis. US. Metuchen N.J.

Keisuke Hirano. (2008). Decision theory in econometrics. The New Palgrave Dictionary of Economics.

Kennedy, P. (2003). A guide to econometrics. Cambridge, Mass: MIT Press.

M. Krishna Moorthy. (2012). A Study on Factors Affecting the Performance of SMEs in Malaysia. International Journal of Academic Research in Business and Social Sciences.

Mathew Philip. (2010). Factors affecting business success of small \&medium enterprises (SMEs). The University of Stirling Journal, UK.

Mohammed Nasir Uddin. (2014). Factors Affecting Enterprises' Adaptation Strategies to Environmental Degradation and Climate Change Effects: A Farm Level Study in Bangladesh. International Food Policy Research Institute (IFPRI): Washington, DC, USA.

Moore, David, George P. McCabe, \& Bruce Craig. (2012). Introduction to the practice of statistics. New York: W.H. Freeman.

Mullins, L. (2002). Management and Organizational Behavior. Harlow, Financial Times Prentice Hall.

Parisa Salimzadeh. (2013). Sustainability in Small and Medium Sized Enterprises in Regional Australia: A Framework of Analysis. Annual SEAANZ Conference Proceedings in Sydney, Australia.

Pelham, A. (2000). Market orientation and other potential influences on performance in small and medium-sized manufacturing firms. Journal of Small Business Management.

Probability, econometrics and truth. (2000). The methodology of econometrics. By Hugo A. Keuzenkamp Published by Cambridge University Press.

Syed A Hayat. (2014). Indonesian Global Expansion: A Case Study. International Journal of Global Business.

V. Krishnamurthy. (2009). Enhancing firm level competitiveness Indian leather and footwear industry. Strategic and Road map development. A report for MMCC, India.

Wang, C., Han, X., \& Wen, B. (2003). An empirical study of the relationship between customer's satisfaction and loyalty. Nankai Business Review.

Watkins, A. E., Richard L. Scheaffer, \& George W. Cobb. (2008). Statistics in action: understanding a world of data. Emeryville, CA: Key Curriculum Press.

Wooldridge, J. (2003). Introductory Econometrics: A Modern Approach. Mason: Thomson South-Western.

Yusuff Olabisi Sherifat. (2010). Gender differentials in factors affecting performance of small-scale enterprises. Innovative Issues and Approaches of Social Sciences in Lagos State - Nigeria. 